\title{
Economic Policy Uncertainty and Corporate Investment - Cash Sensitivity
}

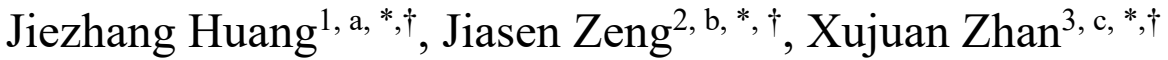 \\ ${ }^{1}$ Zhejiang University, Hangzhou, China \\ ${ }^{2}$ Georgia Tech, Atlanta, US \\ ${ }^{3}$ Sun Yat-sen University, Guangzhou, China

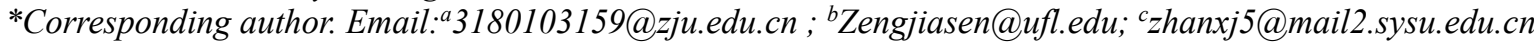 \\ ${ }^{\dagger}$ These authors contributed equally.
}

\begin{abstract}
This paper explores the relationship between economic policy uncertainty (EPU) and corporate investment cash sensitivity. We find that economic policy uncertainty has a significant impact on the investment-cash flow sensitivity of firms. Moreover, these results were still robust after a series of robustness tests and endogeneity treatments. More importantly, this paper finds that EPU impacts firms' investment-cash flow sensitivity mainly by affecting financing constraints (information disclosure, operational risk). Finally, compared with large-scale enterprises, EPU has a more significant impact on the investment-cash flow sensitivity of small-scale enterprises. Compared with enterprises with a high state-owned share ratio, EPU significantly impacts enterprises with a low state-owned share ratio. Moreover, we also find that institutional investors have no significant mitigating effect on the sensitivity of investment cash flow of enterprises impacted by economic policy uncertainties. The data we used was from the Wind data system, and the fixed effect panel was used, and the measurement method was LSDV.
\end{abstract}

Keywords: economic policy uncertainty; Investment cash flow sensitivity.

\section{INTRODUCTION}

The Economic Policy Uncertainty Index (EPU Index) measures macroeconomic and economic policy uncertainty jointly published by Stanford University and the University of Chicago [1]. According to representative media reports of many countries, the index uses text mining technology to measure various countries' macroeconomic and economic uncertainty. Its data provides a good measure of macroeconomic uncertainty. There are two types of EPU index in China calculated by Baker et al. The first type of data is the EPU index calculated by quantifying relevant concepts in 500 newspapers from South China Morning Post. The second type is based on People's Daily and Guangming Daily, and the samples are divided into three periods: Data from the central planning era (1949-1978), the reform and opening era (1979-1999), and globalization era (after 2000).

When analyzing the reason for high investment-cash flow sensitivity, most studies focus on micro factors, like financing constraints and agency costs of the enterprise. Few studies focus on macro factors, like monetary and economic policy. Though, the micro or macro level information is a good explanation for the sensitivity of investment cash flow. These factors fail to give a complete origin of high investment-cash flow sensitivity, including macro and micro perspectives. In this paper, we give a theoretical hypothesis to link macro and micro factors, which is also tested by empirical evidence, to reconcile the relationship between them.

Specifically, we assume that EPU is the cause of financing constraints. From a big investor's point of view, the higher the EPU, the less certainty there is about whether future policies will benefit the industry. This means that operating risk for many businesses could increase and lead investors to demand more compensation for the increased risk. Therefore, the cost of external financing will rise, which means many firms will face financing constraints. As for a firm with financing constraints, compared with the relatively high cost of external financing, firm managers may choose internal financing to reduce the cost, which causes the higher investment-cash flow sensitivity. 
Moreover, under an environment with high EPU, the managements feel more uncertain about the future revenue since they do not know whether the policy change will benefit their firm. Thus, if one chooses external financing to invest in a certain project, the future profit may not offset the high financing cost.

We focus on the impact of EPU on corporate investment in the Chinese market for two reasons [2]. First of all, as the world's second-largest economy and the largest trading nation, China has a huge financial position and development prospects [2]. Whether it is the One Belt and One Road economic construction project proposed by China in 2013, or the connection between the world economic market and the Chinese economic market with Hong Kong as the link, China indicates that today's Chinese economy is in the process of continuously advancing towards the world economy. Therefore, in the face of the continuous growth of China's economic market, we realize that China's economic market is full of huge potential. For Chinese companies, this is both an opportunity and a risk.

Understanding EPU and corporate investment cash flow sensitivity have become the key to the successful expansion of Chinese enterprises [2]. Therefore, we explore the relationship between corporate investmentcash sensitivity and EPU in the Chinese market to seek the positive and negative impacts.

Secondly, as the Chinese market is an emerging market globally, many economic theories aimed at the capitalist economic market cannot be applied directly to the Chinese company. At the same time, as China's economic system is transitioning from a planned economy to a market economy, there are significant policy and economic uncertainties regarding China's economic orientation to the world economy. Because of the financial system of the planned economy, Chinese government policies tend to intervene directly in financial markets and have a huge economic impact. When they conduct external financing, they not only face the impact of costs related to policy uncertainties but also face the risk changes of the external financial market. Therefore, the Chinese market provides a good environment for understanding EPU and corporate investment cash flow sensitivity. At the same time, the connection between EPU and the sensitivity of corporate investment cash flow can also provide a deeper understanding of the effectiveness of resource allocation in China's financial market. And, like Chinese companies, other emerging market economies also face policy uncertainty. Therefore, discussing relevant issues in the Chinese market will also help other emerging markets to provide a case of EPU and corporate investment cash flow sensitivity and help other emerging countries to understand the impact of policy costs on corporate financing.

In this paper, we reconcile the micro and macro factors influencing the investment-cash flow sensitivity and give a complete explanation about the cause of high investment-cash flow sensitivity. Specifically, through empirical analysis, we found the EPU significantly influences the investment-cash flow sensitivity. Moreover, the results of mediating effect test showed that the effect of EPU on the cash of a certain company influences the investment activities by affecting the operational capability.

In this paper, we reconcile the micro and macro factors influencing the investment-cash flow sensitivity and give a complete explanation about the cause of high investment-cash flow sensitivity.

Our paper optimizes the data source of EPU. Most of the basic data adopted in the previous papers used the first type of EPU data calculated by Baker: the EPU index calculated quantitatively through the historical data of Xinhua Morning Post. We consider that the SCMP is a Hong Kong newspaper and does not reflect China's overall economic policy uncertainty [3]. Therefore, we use the EPU index of China calculated by Yun Huang from ten newspapers in mainland China as the basic data of the paper. Compared with the economic policy uncertainty indicator used by predecessors in the study of corporate financial problems, the EPU indicator in China used in this paper is the latest research result. It reflects the degree of economic policy uncertainty more accurately and is more in line with the actual situation of China's development.

Our research focus of this paper is based on the practicability of the research and the judgment of the domestic social and economic structure, which is also one of the innovation points of this paper. Therefore, the EPU index was adopted as one of the influencing factors to be included in the model in this paper. Compared with predecessors' economic policy uncertainty indicator in the study of corporate financial problems, this paper uses the EPU indicator as a measuring variable to provide a more accurate response to the degree of economic policy uncertainty.

\section{LITERATURE REVIEW}

\subsection{Investment-cash Sensitivity}

In foreign studies, Fazzari, Hubbard, and Petersen initially found that enterprises generally have a high sensitivity to investment cash flow by studying corporate financing under the condition of information asymmetry in the capital market [4]. Through empirical analysis, they considered that Information asymmetry makes the cost of external financing too high, which leads to high investment-cash flow sensitivity. Specifically, for enterprises with relatively low dividends, their financing constraints are larger, and the sensitivity of investmentcash flow is higher. The financing constraint referred to here is the narrow sense of financing constraint, that is, 
the constraint caused by the funds' inability raised through financing to guarantee the pointed progress of investment activities.

Since then, there have been many studies on investment-cash sensitivity [5]. Kaplan et al. drew an opposite conclusion through research. They pointed out that a single variable of financing constraints does not necessarily cause investment-cash flow sensitivity. For a company that needs financing to complete its investment activities, it is faced with high external financing costs and low internal financing costs at the same time. So, the reason why it chooses internal financing is probably just to reduce costs, which does not mean that it cannot bear external financing costs. That is, the company does not necessarily have financing constraints [6]. In addition, Cleary et al.questioned the conclusions of Fazzari et al.

To reconcile these contradictory empirical analysis conclusions, Moyen et al. constructed two theoretical models: unconstrained model (enterprises can raise external funds) and constrained model (enterprises can't raise external funds) [7]. Low dividend, low cash flow, and constrained model were used as three indicators to judge financing constraints.[4] The results are consistent with those of Fazzari et al. when a low dividend or low cash flow is used to determine the financing constraints of the company.[5] Constraint models were used to obtain the same results as Kaplan et al.

There are also a lot of relevant researches in China [8]. Feng Wei investigated the influence of internal cash flow of listed enterprises on the determination of investment rate, judged the low dividend companies as the situation of financing constraints, and finally concluded that financing constraints mainly caused investment-cash flow sensitivity [9]. Lian Yujun et al. made a comparative analysis of the impact of financing constraints and agency costs on investment-cash flow. He pointed out that listed companies in China as a whole have a higher investmentcash flow sensitivity, and non-financing constraints show a higher investment-cash flow sensitivity [9]. In addition, Lian Yujun et al. found that the factors leading to higher investment-cash flow sensitivity are different for different types of companies by grouping them into different categories. For large-scale companies with a high dividend payout ratio and high state-owned equity ratio, the investment-cash flow sensitivity mainly comes from higher agency costs than the principle of financing constraint.

\subsection{Investment-cash Sensitivity}

We define economic policy uncertainty as the degree of certainty that groups, such as enterprises or organizations, give the future economic policies an overall forecast. The higher the index is, the more confident most companies or organizations are that their predictions of future economic policy changes are correct.
In other words, future policy changes are more predictable.

Based on previous studies on the relationship between investment-cash flow sensitivity and financing constraints, this paper considers economic policy uncertainty an influencing factor. It includes it into the empirical analysis model [9, 10] In the past, scholars often paid attention to analyzing factors at the micro-level when investigating investment-cash flow problems, such as Lian Yujun et al. and Qu Wenzhou et al. However, China is now the world's second-largest economy and a major player in international trade. As an emerging economy, China has been carrying out various economic policy reforms. Therefore, many economic policies are often important indicators for enterprises to adjust the asset structure and significantly impact enterprises' development [11]. For this reason, some scholars also began to pay attention to the study of economic policy uncertainty. For example, Li Jialin et al. studied the impact of economic policy uncertainty factors on corporate investment behavior and investment efficiency and gave relevant policy suggestions.

In this paper, the uncertain economic policy factors are included in the research of corporate investment strategy. Through the empirical analysis of relevant variables, the investment-cash sensitivity is deeply understood, and the relevant economic policy suggestions are put forward.

\section{HYPOTHESIS DEVELOPMENT}

In this paper, we explain both macro and micro perspectives. Specifically, higher EPU, which means people feel more uncertain about the government's future economic policy. For a certain industry, its revenue is highly influenced by economic policy. For example, in China, subsidies for the purchase of new energy vehicles increased the demand and created a larger market for new energy vehicle manufacturers, but also cause the demand for traditional energy vehicles to decrease. As for the investors, if EPU increases, they will feel more uncertain if the firm they invest in will enjoy economic policy benefits in the future. In other words, they are more uncertain about the future operation and hence charge more for the increased risk. As a result, many firms will face financing constraints with a higher cost of external financing. Moreover, higher EPU also makes management more uncertain if the future revenue is enough to pay for the high cost of external financing. The internal financing, which is cheaper and lower in risk, may be their final choice, leading to a higher investmentcash flow sensitivity. Thus, we assume:

H1: Higher EPU will cause the\# increment of investment-cash flow sensitivity.

H2: Higher EPU will lead to financing constraints, which increases the internal financing and decreases the 
external financing, and finally, both higher EPU and financing constraints cause the higher investment-cash flow sensitivity.

\section{DATA AND METHODOLOGY}

\subsection{Research Design}

\subsubsection{Model and Data Setting}

Table 1: Variable definitions

\begin{tabular}{|c|c|c|}
\hline Variable & Symbol & Definition \\
\hline $\begin{array}{l}\text { The degree of } \\
\text { investment }\end{array}$ & $I_{T A}$ & $\begin{array}{l}\text { Business investment } \\
\text { expenditure/total assets of } \\
\text { the previous period }\end{array}$ \\
\hline Cash flow level & $C F_{T A}$ & $\begin{array}{l}\text { Corporate } \\
\text { flow/total assets of the } \\
\text { previous period }\end{array}$ \\
\hline $\begin{array}{c}\text { EPU index } \\
\text { (numerical value) }\end{array}$ & $E P U_{N U M}$ & $\begin{array}{l}\text { An index of economic } \\
\text { policy uncertainty }\end{array}$ \\
\hline $\begin{array}{l}\text { EPU index } \\
\text { (dummy variable) }\end{array}$ & $E P U_{D U M}$ & $\begin{array}{l}\text { The degree of economic } \\
\text { policy uncertainty faced by } \\
\text { firms }\end{array}$ \\
\hline $\begin{array}{l}\text { The adjusted } \\
\text { EPU index }\end{array}$ & $A E P U$ & $\begin{array}{l}1 \text { is high uncertainty, } 0 \text { is } \\
\text { low uncertainty }\end{array}$ \\
\hline Tobin Q & $Q$ & $\begin{array}{l}\text { After taking into account } \\
\text { the previous period size and } \\
\text { cash flow of different } \\
\text { enterprises }\end{array}$ \\
\hline $\begin{array}{l}\text { Asset-liability } \\
\text { ratio }\end{array}$ & $T L_{T A}$ & $\begin{array}{l}\text { The degree of economic } \\
\text { policy uncertainty }\end{array}$ \\
\hline $\begin{array}{l}\text { The ratio of } \\
\text { Income Assets }\end{array}$ & $R_{T A}$ & $\begin{array}{l}\text { The total market } \\
\text { capitalization of } \\
\text { company/total assets }\end{array}$ \\
\hline $\begin{array}{l}\text { The proportion } \\
\text { of } \begin{array}{l}\text { state-owned } \\
\text { shares }\end{array}\end{array}$ & $S S(\%)$ & $\begin{array}{l}\text { Liabilities/total assets of } \\
\text { the previous period }\end{array}$ \\
\hline $\begin{array}{l}\text { Institutional } \\
\text { shareholding ratio }\end{array}$ & $I S R(\%)$ & $\begin{array}{c}\text { Institutional } \\
\text { shareholding ratio }\end{array}$ \\
\hline $\begin{array}{l}\text { Institutional } \\
\text { shareholding ratio } \\
\text { dummy variable }\end{array}$ & $I S R_{D U M}$ & $\begin{array}{l}\text { The institutional } \\
\text { shareholding ratio above the } \\
\text { mean is } 1 . \text { Otherwise, it is } 0\end{array}$ \\
\hline AEPU * ISR & $A E P U_{I S R . D U M}$ & $\begin{array}{l}\text { AEPU multiplied by the } \\
\text { ISR }\end{array}$ \\
\hline CF_TA * ISR & $C F_{T A . I S R . D U M}$ & ISR CF_TA multiplied by the \\
\hline $\begin{array}{l}\mathrm{N} \text { phase leading } \\
\text { variable }\end{array}$ & Fn.Var & $\underset{\text { variable }}{\mathrm{N}}$ phase \\
\hline $\begin{array}{l}\text { Variables with a } \\
\text { lag of } n \text { periods }\end{array}$ & Ln.Var & $\begin{array}{l}\text { Variables with a lag of } n \\
\text { periods }\end{array}$ \\
\hline
\end{tabular}

Based on the analysis of the above theoretical models, the following models are constructed in this paper:

$I_{T A i, t}=\alpha_{0}+\alpha_{1} C F_{T A i, t}+\alpha_{2} A E P U_{i, t}+$ $\alpha_{3} E P U_{N U M t}+\alpha_{4} T L_{T A i, t}+\alpha_{5} R_{T A i, t}+\sum Y e a r+$ $\sum$ Industry $+\epsilon_{i, t}$

For the calculation of EPU DUMt. First calculate the number of EPU, which is $E P \bar{U}_{N U M t}$, divide the TAi,t and get the new variable $E P U_{N U M t} / T A_{i, t}$; For each company first calculate the new variable for the average of the company in different years, Then in the $E P U_{N U M t} / T A_{i, t}$ data of the company, $E P U_{N U M t}$ is set to 1 for the years above the mean. Otherwise it is 0 ; Then calculate, $A E P U_{i, t}=E P U_{D U M i, t} \times(C F / T A)_{i, t} ; T L_{T A I}, T, R_{T A i}$, $T-1$ are the control variables; $\sum Y$ Year and $\sum$ Industry are respectively time fixed effect and industry fixed effect, in which industry classification comes from Shenwan industry.

\subsection{Model and Data Analysis}

\subsubsection{Model Setting Analysis}

To measure the impact of economic policy uncertainty on enterprise investment cash flow, the paper constructs variables Aepui, T. In its construction, different from the practices of some scholars in the past, this paper first deals with the quantitative indicators to measure the economic policy uncertainty, obtains the dummy variable to measure the degree of economic policy uncertainty faced by different enterprises, and then multiplies it by $(C F / T A)_{i . t}$. The main purpose of this method is to avoid the multicollinearity of EPU exponent multiplied by $(C F / T A)_{i . t}$, i.e., $E P U_{N U M i} \times C F / T A_{i . t}$ and $E P U_{N U M t}$ in the model caused by the calculated AEPUI. This is because the volatility of the EPU index is much higher than that of $(C F / T A)_{i}$, which is likely to lead to the unprocessed $A E P U_{i}$. T retains the volatility of the EPU index to a large extent and has a highly similar trend of fluctuation with $E P U_{N U M t}$, thus leading to multicollinearity and affecting the regression results. Adopt dummy variable to calculate $A E P U_{i, t}$, and avoid highly similar fluctuation trend with $E P U_{N U M t}$.

\subsubsection{Extreme Value Processing}

The variables in this paper are almost all divided by the value of TA. If a value close to 0 appears in the sequence of TA, there will be very large data in many variables. At the same time, to avoid deviation between the regression results and the actual situation caused by other extreme values, this paper carried out extreme value processing on the data (using Winsorize processing method to indent the extreme values of the extreme values of the data all variables at the $5 \%$ level).

\subsubsection{Data Sources}

[12] EPU index is the research data of Yun Huang et al., and the sample interval is from 2009 to 2019. Other data were collected from the Wind and CSMAR database, and the sample interval was from 2009 to 2019. The screening principle is as follows:

- Select companies listed and issued A shares before January 1, 2009

- Indent the extreme values of all variables at the 5\% level using Winsorize processing 
- The econometric analysis software was Stata 16.0

- Select companies listed and issued A shares before January 1, 2009

- Indent the extreme values of all variables at the 5\% level using Winsorize processing

- The econometric analysis software was Stata 16.0

\section{EMPIRICAL ANALYSIS}

\subsection{Basic Regression}

Table2. Basic Regression

\begin{tabular}{cllll}
\hline $\begin{array}{c}\text { VARIAB } \\
\text { LES }\end{array}$ & $\begin{array}{l}\text { AVERAG } \\
\mathrm{E}\end{array}$ & $\begin{array}{l}\text { STANDA } \\
\text { RD } \\
\text { ERROR }\end{array}$ & MINIMUM & $\begin{array}{l}\text { MAXIMU } \\
\mathrm{M}\end{array}$ \\
\hline$I_{T A}$ & 0.182 & 0.300 & 0.000315 & 1.144 \\
$C F_{T A}$ & 0.0282 & 0.115 & -0.139 & 0.356 \\
\hline
\end{tabular}

\begin{tabular}{cllll}
\hline$E P U_{N U M}$ & 140.4 & 12.52 & 125.0 & 165.7 \\
$E P U_{D U M}$ & 0.360 & 0.480 & 0 & 1 \\
$A E P U$ & 0.0164 & 0.0820 & -0.139 & 0.356 \\
$Q$ & 2.512 & 2.501 & 0.918 & 10.49 \\
$T L_{T A}$ & 0.512 & 0.263 & 0.127 & 1.062 \\
$R_{T A}$ & 1.022 & 22.75 & -0.0457 & 3754 \\
$S S(\%)$ & 0.359 & 3.816 & 0 & 62.11 \\
$I S R(\%)$ & 37.27 & 23.04 & 1.578 & 76.60 \\
\hline
\end{tabular}

Descriptive statistical analysis

Descriptive test $(\mathrm{N}=45551)$

As shown in the table, compared with the state-owned shareholding ratio, the standard deviation of the institutional shareholding ratio is larger. Its minimum value is $1.578(\%)$ after the tail reduction treatment. Therefore, it can be concluded that, in addition to the heterogeneity of the state-owned shareholding ratio, the heterogeneity of the institutional shareholding ratio is also very important in the study.

Table3. Statistical analysis of correlation

\begin{tabular}{|c|c|c|c|c|c|c|c|c|c|c|}
\hline & $\mathrm{I}_{\mathrm{TA}}$ & $\mathrm{CF}_{\mathrm{TA}}$ & $\mathrm{EPU}_{\mathrm{NUM}}$ & $\mathrm{EPU}_{\mathrm{DUM}}$ & AEPU & $Q$ & $\mathrm{TL}_{\mathrm{TA}}$ & $\mathrm{R}_{\mathrm{TA}}$ & SS(\%) & ISR(\%) \\
\hline $\mathrm{I}_{\mathrm{TA}}$ & 1.000 & & & & & & & & & \\
\hline $\mathrm{CF}_{\mathrm{TA}}$ & 0.037 & 1.000 & & & & & & & & \\
\hline $\mathrm{EPU}_{\mathrm{NUM}}$ & 0.063 & 0.071 & 1.000 & & & & & & & \\
\hline $\mathrm{EPU}_{\mathrm{DUM}}$ & 0.049 & 0.100 & 0.497 & 1.000 & & & & & & \\
\hline AEPU & 0.043 & 0.427 & 0.081 & 0.211 & 1.000 & & & & & \\
\hline Q & 0.144 & 0.192 & 0.058 & 0.045 & 0.139 & 1.000 & & & & \\
\hline $\mathrm{TL}_{\mathrm{TA}}$ & 0.054 & -0.003 & 0.025 & 0.021 & -0.006 & 0.032 & 1.000 & & & \\
\hline $\mathrm{R}_{\mathrm{TA}}$ & 0.060 & 0.079 & 0.070 & 0.141 & 0.082 & 0.106 & 0.005 & 1.000 & & \\
\hline SS(\%) & 0.023 & 0.018 & 0.004 & -0.022 & 0.009 & 0.031 & 0.002 & 0.039 & 1.000 & \\
\hline ISR(\%) & 0.025 & 0.012 & -0.020 & -0.062 & -0.010 & 0.103 & -0.023 & 0.133 & 0.002 & 1.000 \\
\hline
\end{tabular}

The correlation coefficient matrix is shown in the figure. For all the correlation coefficients, they did not exceed 0.5 .

\section{Correlation analysis $(\mathrm{N}=45551)$}

It can be shown in the table that all correlation coefficients are smaller than 0.5 .

Table 4. Regression analysis

\begin{tabular}{cllll}
\hline & $(1)$ & $(2)$ & $(3)$ & $(4)$ \\
VARIABLES & $\begin{array}{l}\text { All } \\
\text { Samples }\end{array}$ & $\begin{array}{l}\text { Fix Time Effect } \\
\text { Added }\end{array}$ & $\begin{array}{l}\text { Industry Fixed } \\
\text { Effect Added }\end{array}$ & $\begin{array}{l}\text { Control } \\
\text { Variables } \\
\text { Added }\end{array}$ \\
\hline$C F_{T A}$ & $0.256^{* * *}$ & $0.172^{* * *}$ & $0.166^{* * *}$ & $0.207^{* * *}$ \\
& $(0.0252)$ & $(0.0251)$ & $(0.0247)$ & $(0.0247)$ \\
$A E P U$ & -0.0530 & $0.111^{* * *}$ & $0.0947^{* * *}$ & $0.0666^{*}$ \\
& $(0.0370)$ & $(0.0370)$ & $(0.0364)$ & $(0.0385)$ \\
$E P U_{N U M}$ & $0.00303^{* * *}$ & $0.00254^{* * *}$ & $0.00235^{* * *}$ & $-0.00142^{* * *}$ \\
& $(0.000171)$ & $(0.000260)$ & $(0.000255)$ & $(0.000258)$ \\
$T L_{T A}$ & & & & $-0.254^{* * *}$ \\
& & & & $(0.00861)$ \\
$R_{T A}$ & & & & $0.000453^{* * *}$
\end{tabular}




\begin{tabular}{cllll}
\hline$Q$ & & & & $(7.29 \mathrm{e}-05)$ \\
& & & $0.0161^{* \star *}$ \\
CONSTANT & $0.612^{* * *}$ & $0.491^{* \star *}$ & $0.442^{* \star *}$ & $(0.000965)$ \\
& $(0.0242)$ & $(0.0370)$ & $(0.0421)$ & $0.811^{* \star *}$ \\
$R-S Q U A R E D$ & 0.020 & 0.050 & 0.085 & $(0.0428)$ \\
YEAR & NO & YES & YES & 0.134 \\
INDUSTRY & NO & NO & YES & YES \\
CONTROL & NO & NO & NO & YES \\
\hline
\end{tabular}

Standard errors in parentheses

$* * * \mathrm{p}<0.01,{ }^{* *} \mathrm{p}<0.05,{ }^{*} \mathrm{p}<0.1$

After processing the data and model according to the relevant conclusions in the model analysis above, this paper conducted regression on the whole data that were not grouped. The model was selected as the fixed-effect model, and the time dummy variable was selected to control the time effect.

Table 5. Regression Results

\begin{tabular}{|c|c|c|c|}
\hline & (1) & (2) & (3) \\
\hline \multirow[b]{2}{*}{ VARIABLES } & $I_{A E P U}$ & & $I_{R . A E P U}$ \\
\hline & $I_{T A}$ & $R_{T A}$ & $I_{T A}$ \\
\hline \multirow[t]{2}{*}{$C F_{T A}$} & $0.207^{\star \star \star}$ & & $0.207^{\star * *}$ \\
\hline & $(0.0247)$ & & $(0.0247)$ \\
\hline \multirow[t]{2}{*}{$A E P U$} & $0.0652^{*}$ & $-8.168^{* * *}$ & $0.0666^{*}$ \\
\hline & $(0.0385)$ & $(1.833)$ & $(0.0385)$ \\
\hline \multirow[t]{2}{*}{$R_{T A}$} & & & $0.000453^{* * *}$ \\
\hline & & & $(7.29 \mathrm{e}-05)$ \\
\hline \multirow[t]{2}{*}{ CONSTANT } & $0.371^{* \star *}$ & -1.881 & $0.811^{* \star *}$ \\
\hline & $(0.0429)$ & $(1.772)$ & $(0.0428)$ \\
\hline$R-S Q U A R E D$ & 0.132 & 0.009 & 0.134 \\
\hline YEAR & YES & YES & YES \\
\hline INDUSTRY & YES & YES & YES \\
\hline CONTROL & YES & YES & YES \\
\hline
\end{tabular}

Standard errors in parentheses

$* * * \mathrm{p}<0.01, * * \mathrm{p}<0.05, * \mathrm{p}<0.1$

As can be seen from the information in the table, the $A E P U$ coefficient is significantly positive, indicating that the economic policy uncertainty has significantly improved the sensitivity of enterprise investment cash flow. The $E P U_{N U M}$ coefficient is significantly negative, indicating that enterprises will reduce investment when economic policy uncertainty increases. $C F_{T A}$ indicates that enterprises generally have significant sensitivity to investment cash flow, which is consistent with the results of previous literatures (such as Lian Yujun et al.). In addition, with the introduction of fixed effects and related control variables, the model's goodness of fit is 
continuously improved and important explanatory variables become significant. It further demonstrates that the fixed effects and control variables selected in this paper can alleviate the problems of missing variables and heterogeneity to a certain extent. By analyzing the regression results of the complete control variable set, hypothesis $\mathrm{H} 1$ is valid.

\subsection{Mediating Effect Test}

To analyze how the effect of EPU on to cash flow of a certain company can influence its investment, we come up with the hypothesis that the EPU, like the high EPU, leads to lower cash flow of a company, and that directly has a negative effect on the operation of the company. With the lower efficiency of operation, which is represented by the operating revenue (TTM), investors probably feel uncertain about the company's future profits and charge a higher payment of their investment. Therefore, with the higher investment cost, the company must choose to cut off part of its future investment.

To prove the hypothesis, we use the mediating effect test, which is implemented by three models:

$$
\begin{gathered}
I_{T A i, t}=\alpha_{0}+\alpha_{1} C F_{T A i . t}+\alpha_{2} A E P U_{i, t}+ \\
\sum \text { Controls }+\sum \text { Year }+\sum \text { Industry }+\epsilon_{i, t} \\
R_{T A i, t}=\alpha_{0}+\alpha_{1} A E P U_{i, t}+\sum \text { Controls }+\sum Y \text { Year }+ \\
\sum \text { Industry }+\epsilon_{i, t} \\
I_{T A i, t}=\alpha_{0}+\alpha_{1} C F_{T A i, t}+\alpha_{2} A E P U_{i, t}+ \\
\alpha_{3} R_{T A i, t}+\sum \text { Controls }+\sum \text { Year }+\sum \text { Industry }+\epsilon_{i, t}
\end{gathered}
$$

According to the regression results, we can conclude AEPU, which is the effect of the EPU to cash flow, has a significant influence on the operating revenue and indirectly influences the investment. Thus, our hypothesis is proved.

To further illustrate the robustness of our results, we changed the method of measuring the variables. Specifically, we use operating revenue (TTM) to replace the total asset to calculate each variable and consider the heterogeneity of the companies.

According to the results, after changing the method of measuring variables, we still obtain the same results. Thus, we can conclude the results of our benchmark regression are robust.

Using the AEPU model, we find no significant relationship between the uncertainty of economic policy and the sensitivity of investment cash flow. To further test, the text puts * AEPU * ahead of two periods, and it is

\begin{tabular}{|c|c|c|}
\hline \multirow[b]{3}{*}{ VARIABLES } & \multirow{2}{*}{$\begin{array}{l}(1) \\
P T_{-} 1\end{array}$} & \multirow{2}{*}{$\begin{array}{l}(2) \\
\text { PT_2 }\end{array}$} \\
\hline & & \\
\hline & $I \_T A$ & $I \_T A$ \\
\hline \multirow[t]{2}{*}{$C F_{-} T A$} & $0.187 * * *$ & $0.159 * * *$ \\
\hline & $(0.0203)$ & $(0.0207)$ \\
\hline \multirow[t]{2}{*}{ F1.AEPU } & -0.0553 & \\
\hline & $(0.0433)$ & \\
\hline \multirow[t]{2}{*}{$F 2 A E P U$} & & -0.0432 \\
\hline & & $(0.0508)$ \\
\hline \multirow[t]{2}{*}{ CONSTANT } & $0.381 * * *$ & $0.785 * * *$ \\
\hline & $(0.0426)$ & $(0.0425)$ \\
\hline$R-S Q U A R E D$ & 0.131 & 0.129 \\
\hline$Y E A R$ & YES & YES \\
\hline INDUSTRY & YES & YES \\
\hline CONTROL & YES & YES \\
\hline
\end{tabular}
found that the regression coefficient of AEPU ahead of two periods is also not significant. Here, F2. AEPU acts as a placebo to test the results, which shows the robustness of the results from another perspective.

Table 6. Placebo test

Standard errors in parentheses

$* * * \mathrm{p}<0.01, * * \mathrm{p}<0.05, * \mathrm{p}<0$.

\section{CONCLUSIONS}

Based on the above empirical analysis results and robustness test results, this paper finally concludes with robustness:

1. The uncertainty of economic policy significantly increases the sensitivity of corporate investment cash flow. When economic policy uncertainty increases, firms reduce investment.

2. The effect of the EPU on cash flow (AEPU) has a significant influence on the operating revenue and indirectly influences the investment.

3. All the research conclusions in this paper have passed the robustness test, which means that the research in this paper is scientific and accurate to a certain extent.

Therefore, based on the results of the article, we give the following conclusions.

1. The national economic policy should pay attention to the control of the transition period. Economic policy uncertainty has a significant impact on the overall market, which is easy to get enterprises into 
financing difficulties and affect social development.

2. Improve the financial market and expand financing channels for enterprises. For enterprises with a low state share ratio and small enterprises, the pressure of external financing is greater. When economic policy uncertainty rises, it is prone to severe financial distress. Therefore, the financial market needs to play its role more efficiently. For example, new loan guarantees for enterprises with low state-owned share ratios and small enterprises can be found through financial innovation to broaden their financing channels.

3. When economic policy uncertainty rises, listed companies need to increase their cash flow appropriately to avoid financial distress. The increase of economic policy uncertainty will generally lead to the increase of investment cash flow sensitivity of enterprises, to correspond to the future investment expenditure. Listed companies need to pay close attention to the rise of economic policy uncertainty and appropriately increase cash flow.

\section{REFERENCES}

[1] Scott R. Baker, Nicholas Bloom,Steven J. Davis.Measuring Economic Policy Uncertainty $[\mathrm{J}]$.The Quarterly Journal of Economics, Volume 131, Issue 4, November 2016, Pages 15931636.

[2] Wang Yizhong, Song Min. Macroeconomic uncertainty, capital demand and firm investment [J]. Economic Research Journal,2014,49(02):4-17

[3] Yun Huang,Paul Luk.Measuring economic policy uncertainty in China[J]. China Economic Review, Volume 59, February 2020, 101367.

[4] Fazzari S, G H ubbard, B Peterson.Financing constraints and corporate investment [J]. Brookings Papers on Economic Activity, 1988, 1: 141 195.

[5] Kaplan S, L Zingales.Do investmentcash flow sensitivities provide useful measures of financial constraints? [ J]. Quarterly Journal of Economics, 1997, 112: $169 \sim 215$.

[6] Cleary, Sean. The Relationship between Firm Investment and Financial Status[J]. The Journal of Finance, vol. 54, no. 2, 1999, pp. 673-692.

[7] Moyen, Nathalie. Investment-Cash Flow Sensitivities: Constrained versus Unconstrained Firms $[\mathrm{J}]$. The Journal of Finance, vol. 59, no. 5, 2004, pp. 20612092.

[8] Feng Wei. Internal Cash Flow and Corporate Investment: Evidence from the Financial Reports of
Listed Companies in China's Stock Market [J]. Economic Science, 1999(01):52-58.

[9] Lian Yujun, Cheng Jian. Investment - Cash Flow Sensitivity: Financing Constraints or Agency Costs? [J]. Journal of Economic Research,2007(02):37-46. (in Chinese)

[10] QU Wenzhou, XIE Yalu, YE Yumei. Information asymmetry, financing constraints and investmentcash flow sensitivity: An empirical study based on market microstructure theory $[\mathrm{J}]$. Economic Research Journal,2011,46(06):105-117.

[11] LI Jialin, DONG Jiachang, ZHANG Qianxiao. Economic Policy Uncertainty, Financing Constraints and Firm Investment [J]. Forum of Statistics and Information Technology,2019,34(10):73-83. (in Chinese)

[12] Yun Huang,Paul Luk.Measuring economic policy uncertainty in China[J]. China Economic Review, Volume 59, February 2020, 101367. 